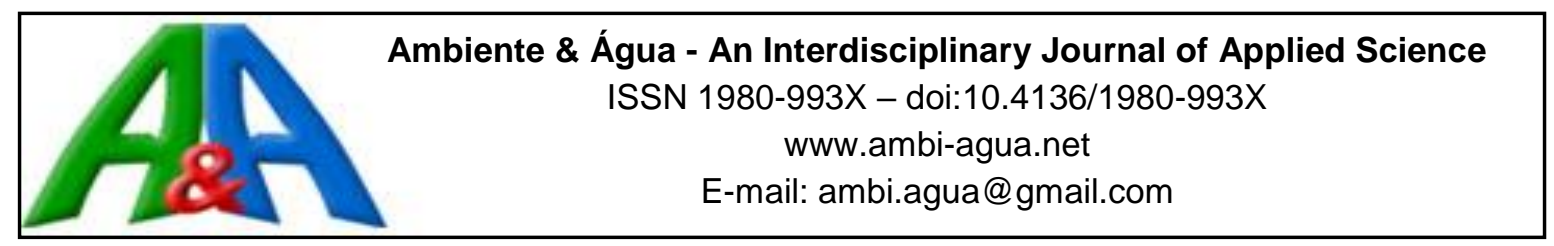

\title{
Water management assessment methodology for urban planning
}

\author{
doi:10.4136/ambi-agua.1917
}

Received: 11 Apr. 2016; Accepted: 24 Nov. 2016

\author{
Giovana Ulian ${ }^{1 *}$; Ivan Cartes ${ }^{1}$; Maria Manuela C. Lemos Lima ${ }^{2}$ \\ ${ }^{1}$ Universidad del Bío-Bío (UBB), Concepción, Chile \\ Departamento Planificación y Diseño Urbano \\ ${ }^{2}$ Universidade do Minho (UM), Campus de Azurém, Guimarães, Portugal \\ Departamento de Engenharia Civil. \\ "Corresponding author: e-mail: giovana.ulian@terra.com.br, \\ cartes@ubiobio.cl,mmlima@civil.uminho.pt
}

\begin{abstract}
One of the biggest challenges in urban planning is to balance the use of natural resources with the need to preserve them. One of the main resources is water, which is essential to human life and activities. Population growth and urban sprawl challenge water availability. Thus, it is important to evaluate development trends in order to predict future scenarios, enabling the adoption of preventive actions and decision-making. The objective of this study is to present a water management assessment methodology for urban planning as a practical and direct tool capable of conveying the necessary information for decision making in the process of balanced and harmonious urban planning, applicable to medium size Brazilian cities.
\end{abstract}

Keywords: evaluation indicators, urban expansion, urban policy.

\section{Metodologia de avaliação da gestão da água para o planejamento urbano}

\section{RESUMO}

Um dos grandes desafios aos planejadores do espaço urbano está em conciliar o uso dos recursos naturais com a necessidade de preservá-los. Neste sentido a água, enquanto recurso natural prioritário, fundamenta a existência e promove as atividades humanas. $\mathrm{O}$ crescimento populacional e a expansão urbana desafiam a disponibilidade de água. Desta forma é essencial diagnosticar os impactos do desenvolvimento para prognosticar cenários futuros, possibilitando nortear ações preventivas e a tomada de decisão. O objetivo deste estudo é apresentar uma metodologia de avaliação diagnóstica para a gestão da água como ferramenta prática e direta que permite auxiliar no levantamento de informações necessárias para o planejamento urbano equilibrado e harmônico, aplicável a cidades brasileiras de porte médio.

Palavras-chave: abastecimento de água, crescimento urbano, indicadores de avaliação. 


\section{INTRODUCTION}

Spatial sustainability is advocated by some urban planners, who believe that compact cities with higher population concentrations facilitate mobility through a more efficient transport system. On another hand, some environment scientists counter that sustainability is achieved by greener, more conservative, self-supplying cities, with smaller population density. As a way to find a solution to this impasse, Agudelo-Vera et al. (2011) state that sustainable urban development should promote the management of scarce resources integrated with urban planning.

It is imperative that more information is developed regarding the environment, especially concerning the hydrologic impacts driven by land-use changes (Tong et al., 2009). The sudden transformation of rural areas into urban areas demands the adoption of strategies that consider the conservation of water resources, and allow changes in a sustainable way.

Despite having a close connection with urban design and land use and occupation, sanitation in Brazil tends merely to meet emerging demands, and does not contribute to the organization of urban space. These sanitation actions are carried out in a non-integrated way, as an answer to immediate problems rather than considering preventive planning or needed improvements (Bernardes et al., 2006). According to Andrade and Blumenschein (2014), research concerning the urban water cycle within a river basin should be linked to studies of urban ecosystems and the constructed environment, considering the spatial organization of the community and landscape patterns. In conventional urban design, urban, hydrologic and environmental concepts are not articulated or considered during town planning processes.

Water flows, considered by Pickett et al. (2013) to be a significant dimension to connect ecology, urban design and social background, have an important role to play in urban systems or "urban ecosystems". Urban sprawl damages water systems and causes drastic changes in hydrologic regimes. In Brazilian municipalities, it is usual to increase water availability without considering strategies that improve water management and could reduce water demand.

There are limits to water availability. The negative impacts associated with the increase of water withdrawal rates for human consumption and the pollution of water bodies must be addressed; it is therefore imperative to adopt planned management of water demand (Thompson, 1999).

"Ecological Urbanism" considers that cities need to adapt to changing human needs, and that water is an important variable to be considered in urban planning (Whiston and Spirn, 2013). The use of multiple limits, such as river basins, parceling, dwellings and natural areas within the urban matrix, emphasizes the ecology capacity to connect the system structure, the management of human choices, design, political interventions, and their consequences to ecological functioning (Pickett et al., 2013).

The use of indicators is considered a fundamental strategy to identify and qualify important aspects of urban inter-relations. Indicators are indexes that can determine changes and the state of a phenomenon, making it possible to monitor its evolution. According to Dos Santos (2004), an indicator can determine the degree of changes and the conditions in the environment and, if well conducted, allows the representation of the causes that exist in a particular environment. Rodríguez et al. (2015) state that the development of indicators concerning the integration of water issues and urban planning will help to quantify their interaction, generating a significant improvement in the application of the Water Sensitive Urban Design (WSUD) concept, and might support mitigating inappropriate planning consequences. WSUD methodology proposed to the city of Melbourne by Barton and Argue (2007) aimed to avoid, or at least minimize, the environmental impact of pollution to a water body caused by building. 
Currently, references concerning the integration of water management as a tool for urban planning are rare according to Dickie et al. (2010), even though it is an appropriate methodology for urban planning.

The project "WATER in CORE" is a pilot-project for river basin water management in the Mediterranean, based in five river basins in Greece, Italy, Spain and Cyprus. This study aims to integrate the principles of Local Agenda 21 with water resources management, resulting in twenty-nine indicators, focused on water preservation and avoidance of water stress. Indicators describe the performance and are categorized as environmental, social and developmental (WaterInCore, 2012).

Castro (2007) gave a questionnaire to representatives of public agencies, water resources managers and researchers so that they attributed weights to the indicators that he had defined. His objective was to propose a methodology for the evaluation of urbanization's effects on water bodies, which could support the managers' decisions regarding the granting of authorizations for construction and water use. He sought to evaluate the most relevant effects of urbanization on water bodies, through the use of multi-criteria analysis methods.

The system SNIS (of the original Portuguese designation: Sistema Nacional de Informações sobre Saneamento, Sanitation National System of Information) has indicators that are used to diagnose water and wastewater public services in Brazilian municipalities and is used as the official sanitation database. These indicators aim to compare performance among municipalities and to facilitate the regulation of services and to improve their management (SNIS, 2010).

Based on these studies, this article presents a methodology to evaluate cities' expansion based on the management of human consumption of water, structured on twenty-six indicators, designated by "Hydricity" indicators. The name Hydricity was created to identify the set of indicators developed in this research, which include water resources, cities, and sustainability concepts. Therefore, hydricity is blend of the words for hydri - referring to water, ci - referring to cities and ty - referring to sustainability (Ulian, 2015).

Monitoring using indicators provides assessment of the current situation and allows one to project trends over time, providing permanent responses to governments and citizens. According to Rodríguez et al. (2015) indicators can be useful to predict future scenarios and guide preventive actions. Despite the apparent popularity of the use of indicators based on the concept of sustainable development, their definition is still very generic and has given rise to multiple interpretations, provoking an explosion of indicator types (Tanguay et al., 2010).

This methodology was developed to assist in the diagnosis of cities development from a water resources point of view, with the objective of rendering operational actions for urban planning. The option for the anthropocentric variables adopted in this article resulted from the fact that the present approach is necessarily focused on the use of water as a resource, which supports the life of the inhabitants of urban areas.

It is important to recognize that the development and the selection of indicators are reflexive and subjective processes (Grunwald, 2004), and this work falls within this concept.

This study focused on medium-sized Brazilian cities, due to their considerable number of inhabitants, the regional importance they play, and the lack of research concerning cities this size as well.

\section{MATERIAL AND METHODS}

This article is part of a broader study, which was carried out in three stages: a) "Hydricity" indicators definition, b) benchmarking definition and c) proposal of an integrated method of the first two stages. Based on Ulian (2015) and Ulian et al. (2015a), who presented the first two stages, the main objective of this paper is the development of an assessment 
methodology through the integration of "Hydricity" indicators. This integration consists of transforming a dimensional value of a qualitative or quantitative indicator into a non-dimensional parameter, allowing the results to be interpreted in a qualitative way and facilitating comparisons. In addition, the integration of indicators is conducted in order to allow analysis as a group of indicators (sectorial) and also globally.

During stage a) indicators definition, care was taken to limit the number of indicators so that the list was sufficiently broad and covered the parameters and criteria previously established. The conceptual cut-off for the definition and choice of indicators was based on the criteria of urban morphology, environmental support capacity and efficiency in water systems. The selected indicators are presented in Table 1 .

Table 1. "Hydricity" indicators and their selection sources.

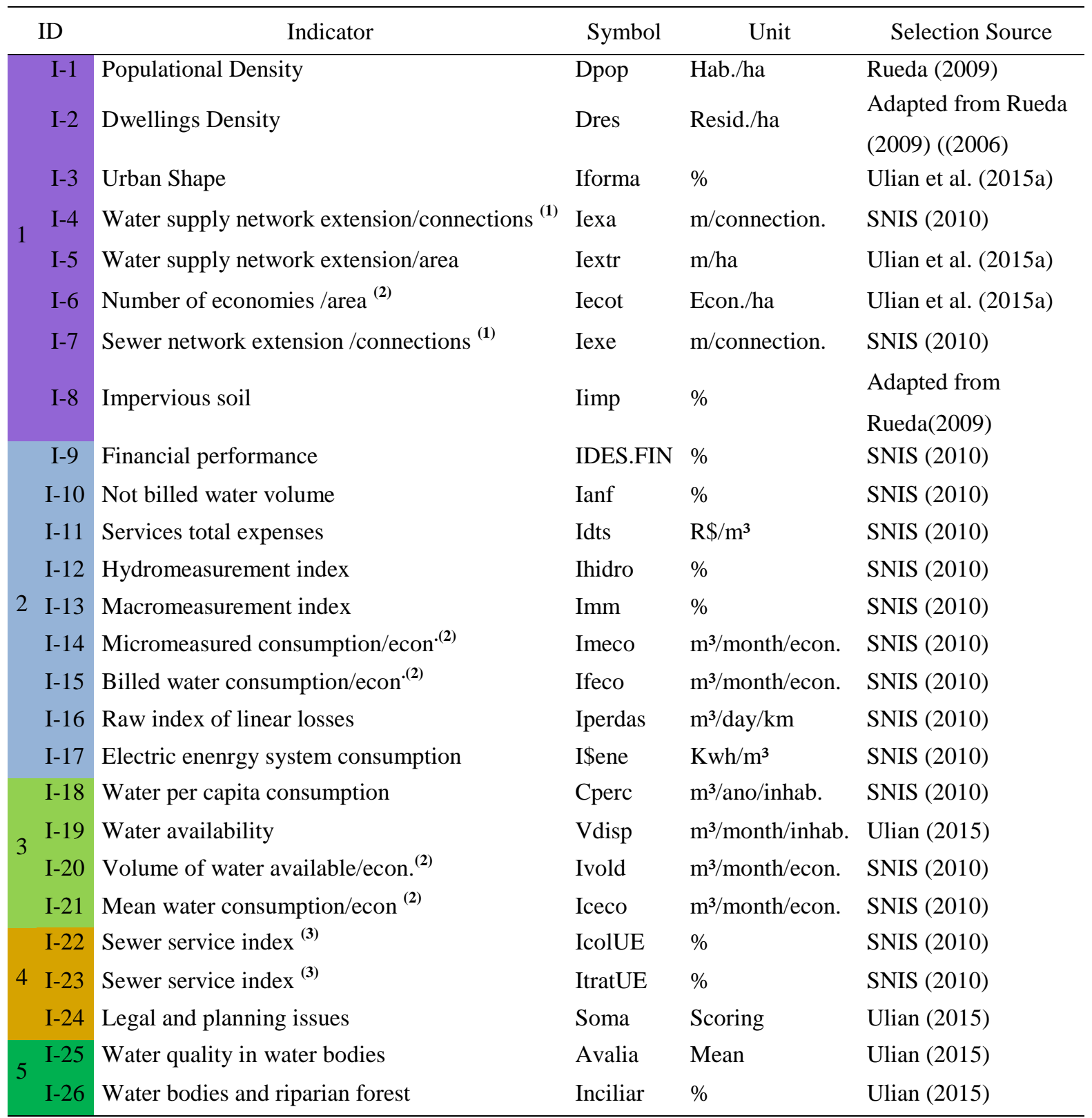

Note: ${ }^{(1)}$ - Network connections: Referring to the number of connections between the main water network and the plot where the building is located. A plot of a multi-family building has only one connection of water or sewage. ${ }^{(2)}$ - Economies referring to all units of land use. Example: a residence, a business, an industry, each one represents an economy. ${ }^{(3)}$ - Indicator I22 refers to sewer drainage and I23 to wastewater treatment. 
Some indicators were created to meet the established criteria. The twenty-six "Hydricity" indicators also went through the analysis of water management and urban planning experts to be validated. Seeking to facilitate the organization and to present the indicators in a sectorial way, they were divided into five groups: Group 1 - Urban Efficiency, comprises indicators related to the use and occupation of land, the shape of the city and the associated water infrastructure; Group 2 - Operational Management of the water supply system, relates to physical and financial control of the water system, from abstraction to distribution; Group 3 Availability versus Consumption, presents aspects related to the availability of water in the territory of the municipality and its relation to demand; Group 4 - Sewage and Legal, is constituted by indicators regarding management of sanitary sewage and the qualitative indicators referring to the legal and technical regulations that the municipality should implement to regulate the urban expansion; Group 5 - Support Capacity, represents the indicators that evaluate the environmental conditions faced with city growth.

To comply with stage c), integration of the "Hydricity" indicators and to enable a diagnostic analysis, it was necessary to comply with stage b) benchmarking definition, i.e. benchmarks that make it possible to compare the results of the calculated indicators. These benchmarks, also called benchmarking literature, were defined as the best and conventional practices benchmarks (Mateus and Bragança, 2009). Benchmarking is presented in Table 2.

Table 2. Adopted Values for best and conventional practices.

\begin{tabular}{|c|c|c|c|c|}
\hline ID & Best Practice & References & $\begin{array}{l}\text { Conventional } \\
\text { Practice }\end{array}$ & References \\
\hline $\mathrm{I}-1$ & 135 & Rueda (2009) & 43 & Cities group $^{(\mathbf{I})}$ \\
\hline $\mathrm{I}-2$ & 85 & Rueda (2009) & 14 & Cities group ${ }^{(\mathbf{1})}$ \\
\hline $\mathrm{I}-3$ & 70 & Vitoria Gasteiz (2014) ${ }^{(2)}$ & 37 & Cities group ${ }^{(\mathbf{1})}$ \\
\hline $\mathrm{I}-4$ & 9.4 & Hypothetical model city ${ }^{(3)}$ & 20.5 & SNIS (2010) \\
\hline $\mathrm{I}-5$ & 158.7 & Hypothetical model city ${ }^{(3)}$ & 139.7 & Cities group ${ }^{(\mathbf{1})}$ \\
\hline I-6 & 51.6 & Hypothetical model city ${ }^{(3)}$ & 17.2 & Cities group ${ }^{(\mathbf{1})}$ \\
\hline $\mathrm{I}-7$ & 9.4 & Hypothetical model city ${ }^{(3)}$ & 15.4 & SNIS (2010) \\
\hline $\mathrm{I}-8$ & 70 & Rueda (2009) & 50 & Brazilian legislation mean ${ }^{(5)}$ \\
\hline $\mathrm{I}-9$ & 97.0 & Vitoria Gasteiz (2014) ${ }^{(2)}$ & 67.8 & SNIS (2010) \\
\hline $\mathrm{I}-10$ & 15.8 & Vitoria Gasteiz (2014) ${ }^{(2)}$ & 27.2 & SNIS (2010) \\
\hline $\mathrm{I}-11$ & 0.06 & SNIS (2010) & 1.04 & SNIS (2010) \\
\hline $\mathrm{I}-12$ & 100 & Maximum value & 86.1 & SNIS (2010) \\
\hline $\mathrm{I}-13$ & 100 & Maximum value & 20 & Assigned value ${ }^{(6)}$ \\
\hline $\mathrm{I}-14$ & 5.3 & Zaragoza (2011) ${ }^{(\mathbf{4})}$ & 16.2 & SNIS (2010) \\
\hline $\mathrm{I}-15$ & 121.0 & Vitoria Gasteiz (2014) ${ }^{(2)}$ & 18.1 & SNIS (2010) \\
\hline $\mathrm{I}-16$ & 1.1 & Vitoria Gasteiz (2014) ${ }^{(2)}$ & 21.8 & SNIS (2010) \\
\hline $\mathrm{I}-17$ & 0.1 & SNIS (2010) & 0.69 & SNIS (2010) \\
\hline $\mathrm{I}-18$ & 40 & UN (1992) & 70 & Rueda (2009) \\
\hline $\mathrm{I}-19$ & 208.2 & ABNT-NBR 12.211(1992) and 2.218 (1994) & 219 & SNIS (2010) \\
\hline $\mathrm{I}-20$ & 93.9 & SNIS (2010) & 24.3 & SNIS (2010) \\
\hline $\mathrm{I}-21$ & 53.0 & Zaragoza (2011) ${ }^{(\mathbf{4})}$ & 40.1 & SNIS (2010) \\
\hline $\mathrm{I}-22$ & 100 & Maximum value & 79 & SNIS (2010) \\
\hline $\mathrm{I}-23$ & 100 & Maximum value & 20 & SNIS (2010) \\
\hline $\mathrm{I}-24$ & 25 & Assigned value ${ }^{(6)}$ & 5 & Assigned value ${ }^{(6)}$ \\
\hline $\mathrm{I}-25$ & Good to excellent & Assigned value ${ }^{(6)}$ & Bad & Assigned value ${ }^{(6)}$ \\
\hline $\mathrm{I}-26$ & 18 & Vitoria Gasteiz (2014) ${ }^{(2)}$ & 30 & CONAMA (2006) \\
\hline
\end{tabular}

Note: ${ }^{(1)}$ - Cities group: referential obtained from the average of medium-sized cities: Piracicaba-SP, Uberlândia-MG, Sorocaba-SP and Juiz de Fora-MG, which stood out in the Sanitation Ranking of the Trata Brasil Institute (2010); ${ }^{(2)}-$ Vitória Gasteiz: calculated values for the city of Vitoria Gasteiz - Spain, considered to be referential for good practices in water management; ${ }^{(3)}$ - Hyphotectical model city: for this indicator, a hypothetical city model was created in order to define best practices; ${ }^{(4)}$ - Zaragoza: calculated values for the city of Zaragoza, Spain, considered to be referential for good practices in water management; ${ }^{(5)}$ - Brazilian legislation mean: several municipal planning legislation was studied and an average value was adopted as referential; ${ }^{(6)}$ - Assigned value: value attributed by the authors based on their work experience. 
Best practice is understood as the referential model, which can be taken as a goal to be achieved. For the best practice referential definition, indicators of cities with recognized performance in sustainable urban management and focus on the preservation of water resources were selected. Some indicators best practices were also selected from the SNIS database (SNIS, 2010). When it was not possible to obtain these references in medium-sized cities, data from cities in other countries were used.

The conventional practice was considered as the minimum value that an indicator should achieve. If the value achieved is below the conventional practice threshold, the city is considered as not concerned with sustainability, especially considering the given indicator. This standard should correspond to the minimum values that regulations, norms and laws should contain.

Once the referential values were established, the following stage was calculated for the city under evaluation. After calculating these indicators, a methodology was necessary to evaluate the values achieved and to integrate the "Hydricity" indicators.

The indicators of Group 1 (Urban Efficiency) are analyzed irrespective of the other groups, using an abacus. This differentiation was made to allow the analysis of the municipality urban efficiency independently of the other indicators. Three abacuses with four axes are drawn, being each half axis representative of an indicator. For benchmarking, an abacus should be designed for best practice values, another with the values of conventional practice and a third abacus with the values of the indicators calculated for the city under evaluation. All abacuses should be drawn using the same scale. The resulting shapes should be compared to evaluate to which shape the cities performance is most similar with, best or conventional practices. Other forms of interpretation could be used, such as overlapping the shapes of the three abacuses. Figure 1 exemplifies a case study carried out in the city of Caxias do Sul, presented in Ulian et al. (2015b).

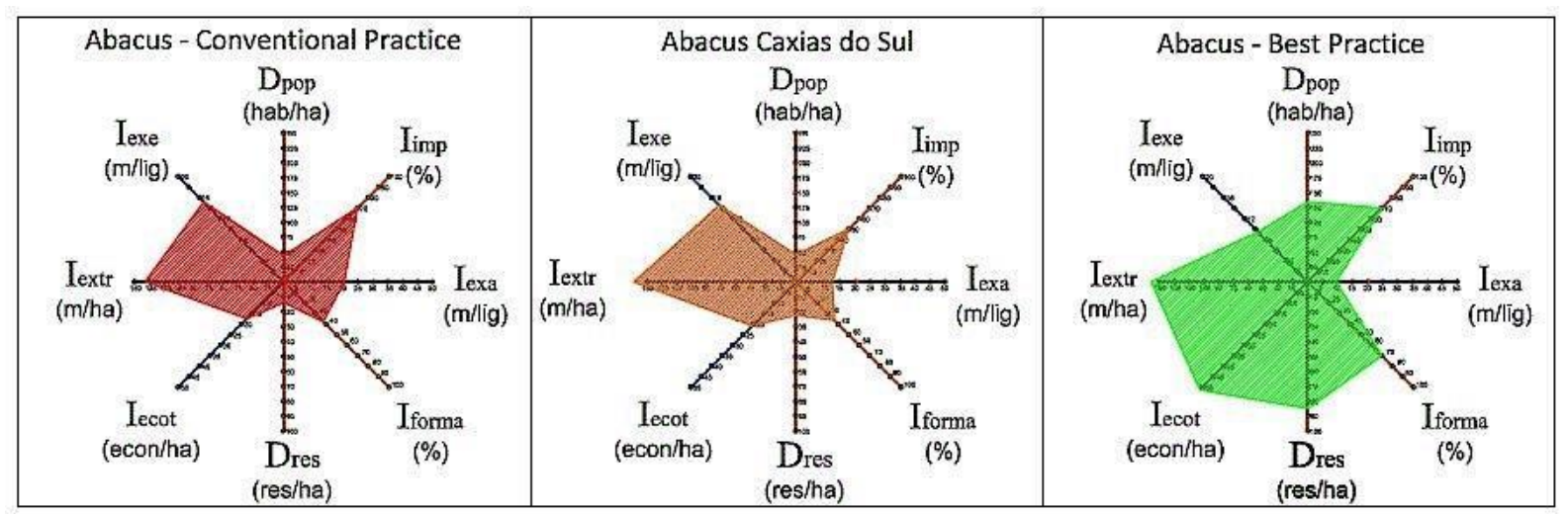

Figure 1. Group 1 application of indicators using comparative abacuses.

Source: Ulian et al. (2015b).

The other indicators, related to Groups 2, 3, 4 and 5, are grouped through normalization of the values and application of a weighting system in two moments. In the first moment, the aggregation of the indicators at a sectorial level is achieved in this way obtaining results for each group. The second weighting is carried out to enable the aggregation of the four groups in a single score. The aggregation process is based on the SBTool ${ }^{\mathrm{PT}}$ methodology (Mateus and Bragança, 2009). Figure 2 presents a schematic description of the evaluation process.

The evaluation process for the indicators of Groups 2, 3, 4 and 5 is divided into three phases:

- Phase 1: Performance quantification at indicator level: allows isolated analyses; 
- Phase 2: Performance quantification at group level: allows sectorial analysis; and

- Phase 3: Quantification of "Hydricity" Global Level: allows global analysis.

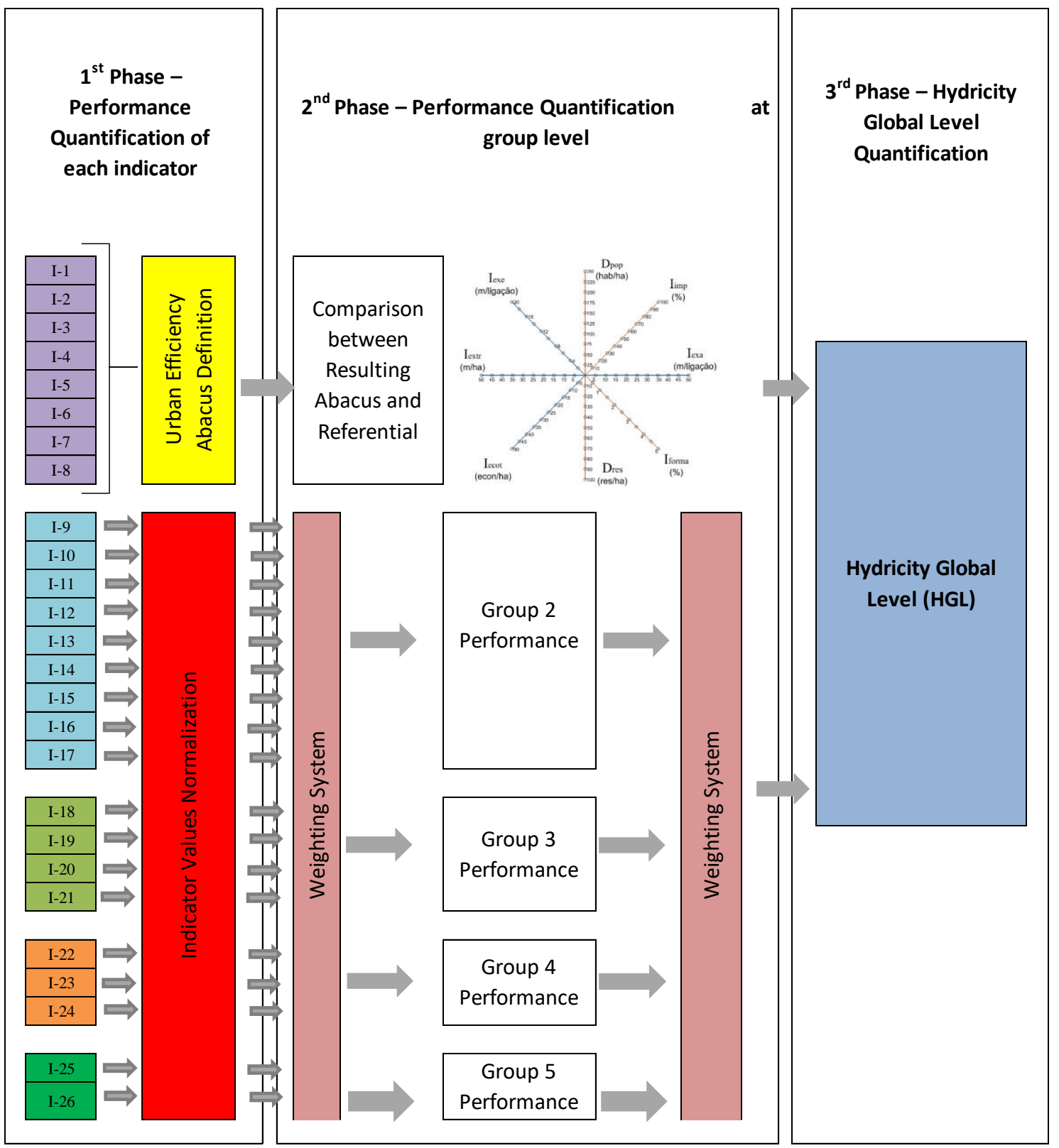

Figure 2. Summary of the proposed method.

The performance evaluation at the level of each indicator corresponds to the quantification of the parameters and the normalization, as described:

a) Quantification of Parameters: the method used to quantify each indicator, i.e. application of the calculation process and definition of best and conventional practice referential. The equations for the quantification of each indicator were presented in Ulian (2015);

b) Normalization: it aims to establish a dimensionless value that expresses the performance of each indicator concerning the referential presented. The weighting systems assigned to normalization were presented in Ulian (2015), see Table 5. From the normalization, it is possible to have an isolated evaluation for each indicator. The 
Diaz-Balteiro Equation 1 was used in the normalization process (Mateus and Bragança, 2009).

$$
\overline{\mathrm{P}}_{\mathrm{i}}=\frac{\mathrm{P}_{\mathrm{i}}-\mathrm{P} *_{\mathrm{i}}}{P i^{*}-\mathrm{P} *_{\mathrm{i}}} \forall_{\mathrm{i}}
$$

where:

$\overline{\mathrm{P}}_{\mathrm{i}}$ is normalization result of parameter $\mathrm{i}, \mathrm{Pi}$ is the quantification value, and

$\mathrm{Pi}^{*}$ and $\mathrm{P} * \mathrm{i}$ are the benchmarks of the parameter $\mathrm{i}$, representing the levels of best and conventional practices, respectively.

The use of Equation 1 allows converting parameters' values on a dimensionless scale, where the value 0 (zero) corresponds to the conventional practice and the value 1 to the best practice level. If the indicator value is greater than the best practice, or smaller than that of conventional practice, the parameter's normalized value assumes a value greater than 1 and smaller than 0, respectively. In any case, to avoid distortions in the aggregation of the indicators/groups, the normalized values to be considered cannot be smaller than -0.2 and greater than 1.2, as recommended by Mateus and Bragança (2009).

Table 3 presents the equivalence used in the conversion of the normalized value.

Table 3. Equivalence used in the conversion of the normalized value.

\begin{tabular}{cc}
\hline $\begin{array}{c}\text { Qualitative } \\
\text { scale }\end{array}$ & Normalized value \\
\hline A $^{*}$ & $\overline{\mathrm{P}}>1.00$ \\
$\mathrm{~A}$ & $0.70 \overline{<\mathrm{P}} \leq 1.00$ \\
$\mathrm{~B}$ & $0.40 \overline{<\mathrm{P}} \leq 0.70$ \\
$\mathrm{C}$ & $0.10 \overline{<\mathrm{P}} \leq 0.40$ \\
$\mathrm{D}$ & $0.00 \overline{\mathrm{x}} \leq 0.10$ \\
$\mathrm{E}$ & $\overline{\mathrm{P}}<0.00$ \\
\hline
\end{tabular}

Source: adapted from Mateus and Bragança (2009).

For the performance quantification at the groups' level and quantification of the "Hydricity" Global Level (HGL), it is necessary to aggregate indicators, based on weighting systems. Aggregation is achieved on two levels:

- Group level: indicators are combined to summarize their performance at the level of each of the four thematic groups (G2, G3, G4, G5);

- "Hydricity" Global Level (HGL): after evaluating the city performance at groups level and analyzing the abacus with the indicators of G1, the last aggregation consists of synthesizing a single value (HGL), which represents the overall performance of the city. In the aggregation process of G2, G3, G4 and G5 equation (2) is used.

$$
\mathrm{I}_{\mathrm{j}}=\sum_{\mathrm{i}=1}^{\mathrm{n}} \mathrm{w}_{\mathrm{i}} \mathrm{x}_{\mathrm{i}}
$$

where:

Ij corresponds to the macro indicator value resulting from weighting of each indicator, category, or dimension (Ii) with the respective weight factor (wi) in the sustainability assessment. The sum of the weights used to obtain each of the three levels of macro indicators 
shall be equal to 1 .

The weighting factors to aggregate the indicators into groups (G2, G3, G4 and G5), and these should be pre-established into the "Hydricity" Global Level. According to Mateus and Bragança (2009). It is widely known that several decision makers prefer to communicate sustainability through a graduated scale. This represents not only the city's performance but also its performance against best and conventional practices (benchmarks). The normalized values are converted to a qualitative scale between E (lower "Hydricity") and A* (higher "Hydricity"), using equivalences shown in Figure 3. In this qualitative scale, level D represents the conventional practice and level A corresponds to best practice.

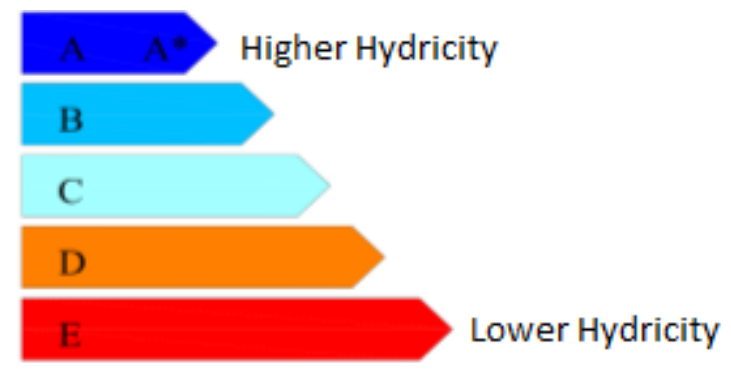

Figure 3. Graduated scale for city certification.

Source: adapted from Mateus and Bragança (2009).

\section{RESULT AND DISCUSSION}

An urban design that is more sensitive to water needs is of concern to managers. The dispersed city model may threaten the availability of water supply, which is especially detected when the river basin is adopted as the basic planning unit.

Other approaches that integrate issues concerned with water and urban sprawl began with a pioneering WSUD (2008) concept in Australia. This indicates that urban planning can be a valuable resource for improving habitability and support water-related ecosystems. However, much more comprehensively than the method proposed here, WSUD integrates all elements of the water cycle, and their interconnections are concomitantly considered to achieve a result that allows a healthy natural environment and that meets the needs of humans, including water for human consumption, wastewater and pollution, precipitation and runoff, watercourses and water resources, and floods. From this, it is concluded that more indicators should be added to the model proposed here, in order to fully diagnose the city's water.

According to the study, "Protecting Water Resources with Higher-Density Development" (US-EPA, 2006), higher-density development could better protect regional water quality, because it consumes less land to accommodate the same number of dwellings and requires best practices in run-off management, according to their context and densities. This approach ratifies the importance given to the indicators that associate the variables density and urban shape in the present study.

These approaches demonstrate that the proposed model is adjustable and can be improved with the addition of other indicators, especially those related to rainwater, which has no direct indicator. These comparisons point out possible improvements for the "Hydricity" assessment method; however, it is important to bear in mind that these studies were not developed for the Brazilian reality and are at a different stage of development.

In what concerns the integration method, it is important to interpret the results obtained from the indicators, making it possible to compare cities in sectorial and global ways, especially if there are regional planning initiatives or at the river basin level. 
However, the HGL must not be analyzed separately, since a critical analysis of the results is necessary, always one has to analyze the specific aspects of each indicator and the sectorial aspects of the groups. HGL is a relevant global result that can be used to foster the action of public agents and still serve for monitoring. The integration method can be used even if it is necessary to increase or reduce the number of indicators, which allows its adaptation to different cities, according to their peculiarities, just by adjusting the weighting system.

Another important aspect to be considered is that Group 1 indicators could also be standardized and integrated into the HGL calculation, facilitating the interpretation of the final result. However, it is important to have an independent format to evaluate the city's urban efficiency, where aspects of the city's shape and structural issues are confronted. If indicators are added to this group, and the abacus analysis system is maintained, it is important that it occurs in pairs so that a new axis is added to the abacus. It is understood that the abacus analysis can go beyond the simple comparison of the resulting shapes to perform a thorough analysis.

To exemplify the application of the method, Tables 4 and 5 present a case study in the city of Caxias do Sul which is a municipality in the state of Rio Grande do Sul (Brazil) with 435,482 inhabitants, with only $3.7 \%$ people living in rural areas (IBGE, 2010). With a total territorial area of $1,644 \mathrm{~km}^{2}$, it has only $744 \mathrm{~km}^{2}(45 \%)$ classified as rural areas. During its history, it has faced many problems due to lack of water, since it does not have rivers with high flow rates in its territory and it captures water in reservoirs originated by dams built in small river streams.

As can be observed, Caxias do Sul obtained a B, in the "Hydricity" Global Level. At the group's level, a B was obtained by two groups and an A* by another group. The lowest result occurred for Group 5, with a $\mathrm{C}$ rating. Caxias do Sul is far from the best practice in Group 1 (Figure 1), illustrating that it can improve significantly in Urban Efficiency, especially in the indicators related to the density and urban shape.

Table 4. Normalization and performance evaluation at the indicator level.

\begin{tabular}{|c|c|c|c|c|c|c|c|}
\hline Group & ID & $\begin{array}{l}\text { Value for Caxias } \\
\text { do Sul }\end{array}$ & $\begin{array}{c}\text { Best } \\
\text { Practice }\end{array}$ & $\begin{array}{l}\text { Conventional } \\
\text { Practice }\end{array}$ & Normalization* & $\begin{array}{c}\text { Adjusted } \\
\text { Normalization* }\end{array}$ & $\begin{array}{l}\text { Performance at } \\
\text { the Indicator } \\
\text { Level }\end{array}$ \\
\hline \multirow{9}{*}{2} & I-9 & 82.4 & 97.0 & 67.8 & 0.50 & 0.50 & B \\
\hline & $\mathrm{I}-10$ & 54.0 & 15.8 & 27.2 & $-2.35^{*}$ & $-0.20 *$ & $\mathrm{E}$ \\
\hline & $\mathrm{I}-11$ & 4.7 & 0.1 & 1.0 & $-3.69 *$ & $-0.20 *$ & $\mathrm{E}$ \\
\hline & $\mathrm{I}-12$ & 98.5 & 100.0 & 86.1 & 0.89 & 0.89 & A \\
\hline & I-13 & 30.0 & 100.0 & 20.0 & 0.13 & 0.13 & $\mathrm{C}$ \\
\hline & I-14 & 105.2 & 5.3 & 16.2 & $-8.19 *$ & $-0.20 *$ & $\mathrm{E}$ \\
\hline & $\mathrm{I}-15$ & 103.7 & 121.0 & 18.1 & 0.83 & 0.83 & A \\
\hline & I-16 & 11.0 & 1.1 & 21.8 & 0.52 & 0.52 & $\mathrm{~B}$ \\
\hline & $\mathrm{I}-17$ & 0.010 & 0.10 & 0.69 & 1.15 & 1.15 & $A^{*}$ \\
\hline \multirow{4}{*}{3} & I-18 & 56.8 & 40 & 70.0 & 0.44 & 0.44 & B \\
\hline & I-19 & 533.7 & 208.2 & 219.0 & -29.14 & $1.2 * *$ & $A^{*}$ \\
\hline & $\mathrm{I}-20$ & 225.4 & 93.9 & 24.3 & $2.89 *$ & $1.20^{*}$ & $A^{*}$ \\
\hline & $\mathrm{I}-21$ & 133.7 & 53 & 40.1 & $7.26 *$ & $1.20 *$ & $A^{*}$ \\
\hline \multirow{3}{*}{4} & $\mathrm{I}-22$ & 101.9 & 100 & 79.0 & 1.09 & 1.09 & $A^{*}$ \\
\hline & $\mathrm{I}-23$ & 16.5 & 100 & 20.0 & -0.04 & -0.04 & $\mathrm{E}$ \\
\hline & $\mathrm{I}-24$ & 18.0 & 25 & 5.0 & 0.65 & 0.65 & B \\
\hline \multirow[t]{2}{*}{5} & $\mathrm{I}-25$ & 4 & 82 & 3 & 0.01 & 0.01 & D \\
\hline & I-26 & 24 & 18 & 30 & 0.5 & 0.5 & B \\
\hline
\end{tabular}

*adjusted because values smaller than -0.2 and higher than 1.2 cannot be used.

**adjusted because the value of the best practice is smaller than the value of the conventional practice. 
Table 5. Performance at the group level and HGL.

\begin{tabular}{|c|c|c|c|c|c|c|c|c|c|}
\hline Group & ID & $\begin{array}{c}\text { Adjusted } \\
\text { Normalization }\end{array}$ & $\begin{array}{l}\text { Performance at } \\
\text { the Indicator } \\
\text { Level }\end{array}$ & $\begin{array}{c}\text { Indicator } \\
\text { WHEIGHT } \\
(\%)\end{array}$ & $\begin{array}{c}\text { Group } \\
\text { WHEIGHT } \\
(\%)\end{array}$ & \multicolumn{2}{|c|}{$\begin{array}{l}\text { Aggregation at } \\
\text { the group level }\end{array}$} & \multicolumn{2}{|c|}{$\begin{array}{c}\text { Hydicity Global } \\
\text { Level (HGL) }\end{array}$} \\
\hline \multirow{9}{*}{2} & I-9 & 0.50 & B & 18 & \multirow{9}{*}{25} & \multirow{9}{*}{0,41} & \multirow{9}{*}{ B } & \multirow{18}{*}{054} & \\
\hline & $\mathrm{I}-10$ & -0.20 & E & 10 & & & & & \\
\hline & I-11 & -0.20 & E & 8 & & & & & \\
\hline & $\mathrm{I}-12$ & 0.89 & A & 10 & & & & & \\
\hline & $\mathrm{I}-13$ & 0.13 & $\mathrm{C}$ & 12 & & & & & \\
\hline & $\mathrm{I}-14$ & -0.20 & E & 8 & & & & & \\
\hline & $\mathrm{I}-15$ & 0.83 & A & 8 & & & & & \\
\hline & $\mathrm{I}-16$ & 0.52 & B & 16 & & & & & \\
\hline & $\mathrm{I}-17$ & 1.15 & $\mathrm{~A}^{*}$ & 10 & & & & & $B$ \\
\hline \multirow{4}{*}{3} & I-18 & 0.44 & B & 20 & \multirow{4}{*}{25} & \multirow{4}{*}{1,05} & \multirow{4}{*}{$\mathrm{A}^{*}$} & & \\
\hline & I-19 & 1.20 & $\mathrm{~A}^{*}$ & 30 & & & & & \\
\hline & $\mathrm{I}-20$ & 1.20 & $A^{*}$ & 30 & & & & & \\
\hline & $\mathrm{I}-21$ & 1.20 & $A^{*}$ & 20 & & & & & \\
\hline \multirow{3}{*}{4} & $\mathrm{I}-22$ & 1.09 & $A^{*}$ & 30 & \multirow{3}{*}{15} & \multirow{3}{*}{0,57} & \multirow{3}{*}{$\mathrm{B}$} & & \\
\hline & $\mathrm{I}-23$ & -0.04 & E & 30 & & & & & \\
\hline & $\mathrm{I}-24$ & 0.65 & B & 40 & & & & & \\
\hline \multirow{2}{*}{5} & $\mathrm{I}-25$ & 0.01 & D & 50 & \multirow{2}{*}{35} & \multirow{2}{*}{0,26} & \multirow{2}{*}{$\mathrm{C}$} & & \\
\hline & $\mathrm{I}-26$ & 0,5 & B & 50 & & & & & \\
\hline
\end{tabular}

The analysis of the abacus together with the aggregation process of the group-level indicators should make it possible to validate the "Hydricity" Global Level. Caixas do Sul achieved a HGL score of B, through the aggregation of the performances of groups 2 to 5 . Thus, the following question should be asked: by the analysis of the abacus of Caxias do Sul for the indicators of Group 1, is it possible that "Hydricity" Global Level could be improved to an A? The answer is no, since Caxias do Sul's abacus shape is far from the best practices abacus. On another hand, the results for Group 1 would lower the HGL rating to C.

Based on this application, it is concluded that the method is good, with possible adjustments to be made and also broadening the indicators, especially those related to Group 5 - Support Capacity. These latter indicators are the most difficult to measure because they depend on geo-referenced data and accurate information. Certainly with more indicators of Support Capacity, the HGL of Caxias do Sul would be smaller. Another group that deserves revision is Group 3, since it considered the availability of water throughout the territory of the municipality, without analyzing the costs to collect water in very distant places. Due to the knowledge of the Caxias do Sul reality, it is believed that the HGL should not be higher than $\mathrm{C}$ and not smaller than $\mathrm{D}$, if the process is reviewed as a whole.

\section{CONCLUSION}

The main objective of the present study was to present indicators and means for their aggregation, i.e. to propose an assessment methodology that would allow a comparative analysis and the monitoring of cities. It was concluded that the proposed method can be a good strategy to perform diagnoses, although requiring adaptations to local specificities.

Despite the attempt to elaborate a practical and direct methodology to be used in urban management, it was concluded that municipalities require a minimum team of professionals. They should focus on the definition of diagnostic procedures, on the organization of the database, on-site supervision of monitoring stations, on decision-making, and on public 
policy-making, even at regional scale, allowing the diagnostic of conflicts between municipalities. Furthermore, it could be possible to monitor the effects of decision making. It was verified that the maximum simplification and practicality implemented respected the depth limits that the variables required. All these analyses were considered pertinent and relevant because they can be used for decision making in city management, enabling the improvement of their conditions.

\section{REFERENCES}

AGUDELO-VERA, C. M.; MELS, A. R.; KEESMAN, K. J.; RIJNAARTS, H. H. Resource management as a key factor for sustainable urban planning. Journal of Environmental Management, v. 92, n. 10, p. 2295-2303, 2011. http://dx.doi.org/10.1016/j.jenvman.2011.05.016

ANDRADE, L. M. S.; BLUMENSCHEIN, R. N. A nova Ecologia da Cidade: uma conexão importantes para a ciência e o Desenho Urbano. In: SEMINÁRIO NACIONAL SOBRE O TRATAMENTO DE ÁREAS DE PRESERVAÇÃO PERMANENTE EM MEIO URBANO E RESTRIÇÕES AMBIENTAIS AO PARCELAMENTO DO SOLO, 3., 10-13 set. 2014, Belém. Anais... Belém: UFPA, 2014.

ASSOCIAÇÃO BRASILEIRA DE NORMAS TÉCNICAS - ABNT. Nbr 12211:1992. Estudos de concepção de sistemas públicos de abastecimento de água - Procedimento. Rio de Janeiro, 1992.

BARTON, A. B.; ARGUE, J. R. A review of the application of water sensitive urban design (wsud) to residential development in Australia. Australian Journal of Water Resources, v. 11 n. 1, p. 31-40, 2007. http://dx.doi.org/10.1080/13241583.2007.11465309

BERNARDES, R. S.; SCÁRDUA, M. P.; CAMPANA, N. A. (Orgs). Guia para a elaboração de planos municipais de saneamento. Brasília: Ministério das Cidades; FUNASA, 2006. 150p.

CASTRO, L. M. A. Proposição de metodologia para a avaliação dos efeitos da urbanização nos corpos de água. Belo Horizonte. 2007. 297f. Dissertação (Programa de Pós-graduação em Saneamento, Meio Ambiente e Recursos Hídricos) - Universidade Federal de Minas Gerais, Belo Horizonte, 2007.

CONSELHO NACIONAL DE MEIO AMBIENTE - CONAMA (Brasil). Resolução ${ }^{0}$ 369: Dispõe sobre os casos excepcionais, de utilidade pública, interesse social ou baixo impacto ambiental, que possibilitam a intervenção ou supressão de vegetação em Área de Preservação Permanente-APP. Diário Oficial [da] União, n. 61, 29 mar. 2006, Seção 1, p. 150-151.

DICKIE, S.; MCKAY G.; IONS, L.; SHAFFER, P. CIRIA C687, Planning for SUDS: making it happen. London: CIRIA C68, 2010. 14p

DOS SANTOS, R. F. Planejamento ambiental, teoria e pratica. São Paulo: Oficina de Textos, 2004. 184 p.

GRUNWALD, A. Strategic knowledge for sustainable development: the need for reflexivity and learning at the interface between science and society. International Journal of Foresight and Innovation Policy, v. 1, n. 1, p. 150-167, 2004. http://dx.doi.org/10.1504/IJFIP.2004.004619 
INSTITUTO BRASILEIRO DE GEOGRAFIA E ESTATÍSTICA - IBGE. Demographic Census. 2010. Available in: http://censo2010.ibge.gov.br. Access in: Sep. 2016.

INSTITUTO TRATA BRASIL. Website. 2010. Available in: http://www.tratabrasil.org.br/. Access in: Sep. 2016.

MATEUS, R.; BRAGANÇA, L. Guia de Avaliação SBToolPT-H. Portugal: Associação iiSBE, 2009. Available in: http://www.mma.gov.br/port/conama/legiabre.cfm?codlegi=489. Access in: Oct. 2014.

PICKETT, S. T. A.; CADENASSO, M. L.; MCGRATH, B. Resilience in ecology and urban design: linking theory and practice for sustainable cities. New York: Springer Science, 2013. 499 p.

RODRÍGUEZ, M. I.; CUEVAS, M. M.; HUERTAS, F.; MARTÍNEZ, G.; MORENO, B. Indicators to evaluate water sensitive urban. WIT Transactions on The Built Environment, v. 168, n. 1, p. 371-382, 2015.

RUEDA, S. (Org.). Plan de indicadores de Sostenibilidad de Vitória Gasteiz. Vitoria Gasteiz: BCN Ecologia, 2009.

SISTEMA NACIONAL DE INFORMAÇÕES SOBRE SANEAMENTO - SNIS (Brasil). Diagnosis of water and sewage services. 2010. Available in: http://www.snis.gov.br/. Access in: Sep. 2016.

TANGUAY, G. A.; RAJAONSON, J.; LEFEBVRE, J-F.; LANOIE, P. Measuring the sustainability of cities: an analysis of the use of local indicators. Journal Ecological Indicators, v. 10, n. 2, p. 2010, 407-418, 2010. http://dx.doi.org/10.1016/j.ecolind.2009.07.013

THOMPSON, S. A. Water demand supply: management and planning. In: Water use, management, and planning in the united states. San Diego: Academic Press, 1999. p. 173-209. http://dx.doi.org/10.1016/B978-012689340-3/50006-2

TONG, S. T. Y.; LIU, A. J.; GOODRICHB J. A. Assessing the water quality impacts of future land-use changes in an urbanizing watershed. National Risk Management Research Laboratory, Cincinnati, Ohio, USA. Environmental Protection Agency Civil Engineering and Environmental Systems, v. 26, n. 1, p. 3-18, 2009. http://dx.doi.org/10.1080/10286600802003393

ULIAN, G. Avaliação Diagnóstica para a Gestão Urbana através de indicadores de "Hidricididade". 2015. PhD Thesis (PhD in Arquitecture and Urbanism) - Facultad de Arquitectura, Construción y Diseño, Universidad del BioBio, Concepción, 2015.

ULIAN, G.; LIMA, M.; CARTES, I. Indicadores de "Hidricidade" como ferramenta de avaliação da eficiência urbana. In: LATIN AMERICAN AND EUROPEAN CONFERENCE ON SUSTAINABLE BUILDINGS AND COMMUNITIES, 2015, 2123 July, Guimarães. Proceedings... Lisbon: Multicomp, 2015. v. 2. p. 11811190. 2015a.

ULIAN, G.; PINO QUILODAN, M. A.; LIMA, M.; CARTES, I. Aplicação de avaliação diagnóstica da eficiência urbana através de indicadores de "Hidricidade" ao município de Caxias do Sul. SIMPÓSIO DE HIDRÁULICA E RECURSOS HÍDRICOS DOS PAÍSES DE LÍNGUA PORTUGUESA, 12., 2015, Brasília. Trabalhos... São Paulo: ABRH, 2015b. 
UNITED NATIONS - UN. Universal declaration of water rights. $22^{\text {nd }}$ ed. Geneva, 1992.

UNITED STATES. Environmental Protection Agency - US-EPA. Protecting water resources with higher-density development. Washington, DC, 2006.

VITORIA GASTEIZ. Centro de Estudios Ambientales. Sistema de Información Ambiental. Atlas ambiental. Vitoria Gasteiz, 2014. Available in: http://www.vitoria- gasteiz.org. Access in: Sep. 2016.

WATER IN CORE. Sustainable water management through common responsibility enhancement in Mediterranean Rivers Basins. Rome: EuropaBook, 2012. p. 20.

WATER SENSITIVE URBAN DESIGN PROGRAM - WSUD. City of Melbourne WSUD guidelines applying the model SUD guidelines. Melbourne: Melbourne Water, 2008. p. 43.

WHISTON, A.; SPIRN, A. Ecological urbanism: a framework for the design of resilient cities. In: PICKETT, S. T. A.; CADENASSO, M. L.; MCGRATH, B. (Eds.). Resilience in ecology and urban design: Linking theory and practice for sustainable cities. Dordrecht: Springer Science Business, 2013.

ZARAGOZA. Ordenanza municipal para la ecoeficiencia y la calidad de la gestión integral del agua. Zaragoza, 2011. Available in:

http://www.zaragoza.es/ciudad/normativa/detalle_Normativa?id=1542. Access in: Sep. 2016. 